\title{
CORDIERITE-SPINEL-QUARTZ ASSEMBLAGES: A POTENTIAL GEOBAROMETER
}

\author{
FRIEDRICH SEIFERT and JOHN C. SCHUMACHER
}

\begin{abstract}
SEIFERT, FRIEDRICH and SCHUMACHER, JOHN C., 1986: Cordierite-spinelquartz assemblages: A potential geobarometer. Bull. Geol. Soc. Finland 58, Part 1, 95-108.

The composition of $\left(\mathrm{Mg}-\mathrm{Zn}-\mathrm{Fe}^{+2}\right)$-aluminate-spinel coexisting with cordierite and quartz is potentially a sensitive geobarometer in rock types such as cordierite - anthophyllite rocks which are not well suited to most other geobarometers. Calculations based on thermodynamic data and the end member reactions demonstrated that the compositions of $(\mathrm{Mg}-\mathrm{Fe})$ - cordierites and $(\mathrm{Mg}-\mathrm{Fe}-\mathrm{Zn})-$ aluminate spinels are only slightly affected by temperature but the effect of pressure is dramatic. With increasing pressure the $\mathrm{X}_{\mathrm{Mg}}$ of the spinel changes from less than 0.1 at 1 bar to about 0.8 at 9 kbars.

Comparison of pressures derived from this model for natural assemblages with known PT conditions shows good agreement but also points to the necessity of treating the effects of water on the stability of cordierite more quantitatively.
\end{abstract}

Key words: geobarometer, cordierite, spinel, quartz, phase relations, thermodynamic data.

Friedrich Seifert and John C. Schumacher: Mineralogisches Institut, Universität Kiel, West Germany.

\section{Introduction}

Since the classical study by Eskola (1914) on the petrology of the Orijärvi region in southwestern Finland cordierite - anthophyllite rocks have attracted the interest of petrologists and mineralogists because of their peculiar bulk -rock chemistry and their unique assemblages. The protoliths of such rocks and their commonly associated sulfide or deposits (such as at Orijärvi, Outokumpu, or Falun) are believed to have formed by hydrothermal processes and metasomatism at relatively low temperatures and pressures ( $c f$. Treloar et al. 1981). However, the pre- sent mineral assemblages formed in a later metamorphic event at higher temperatures and pressures. Despite the variety of their mineral assemblages, cordierite-anthophyllite rocks are not particularly suited to derive pressure - temperature estimates of this metamorphism by conventional geobarometers, mostly due to the structural and chemical complexities of the orthoamphiboles and their not yet quantified stability relations. On the other hand, Eskola (1914) mentions gahnite-rich spinel as a widespread accessory phase in the cordierite-anthophyllite rocks. It is the purpose of the present study to demonstrate that the assemblage cordierite - 
$\left(\mathrm{Mg}-\mathrm{Zn}-\mathrm{Fe}^{+2}\right)$ aluminate spinel - quartz could be used successfully as a sensitive geobarometer after further calibration.

\section{Theory}

\section{Phase relationships}

For discussing assemblages of cordierite, quartz and spinel the dry system $\mathrm{MgO}-$ $\mathrm{Al}_{2} \mathrm{O}_{3}-\mathrm{SiO}_{2}$ represents a convenient starting point. It has been recognized early (Rankin and Merwin 1918) that, in this system, spinel cannot coexist stably with a $\mathrm{SiO}_{2}$ phase. On the other hand, cordierite-spinel assemblages are stable over a wide range of temperatures and up to water pressures of about $4 \mathrm{kbars}$, where the cordierite - spinel tie-line is broken by enstatite + sapphirine (Seifert 1974).

In the system $\mathrm{ZnO}-\mathrm{Al}_{2} \mathrm{O}_{3}-\mathrm{SiO}_{2}$ no stable cordierite-type compound exists (Behruzi, pers. comm., 1984), and gahnite $\left(\mathrm{ZnAl}_{2} \mathrm{O}_{4}\right)+\mathrm{SiO}_{2}$ form a stable assemblage, at least at high temperatures and low pressures (Bunting 1932). In the combined anhydrous system $\mathrm{MgO}-\mathrm{ZnO}-$ $\mathrm{Al}_{2} \mathrm{O}_{3}-\mathrm{SiO}_{2}$, for which no experimental data exist, we may represent expected phase relationships between cordierite, a $\mathrm{MgAl}_{2} \mathrm{O}_{4}-\mathrm{ZnAl}_{2} \mathrm{O}_{4}$ spinel solid solution and quartz in a plane $\mathrm{SiO}_{2}-\mathrm{MgAl}_{2} \mathrm{O}_{4}-\mathrm{ZnAl}_{2} \mathrm{O}_{4}$ (Figure 1). It is assumed here that cordierite cannot incorporate $\mathrm{Zn}$ for $\mathrm{Mg}$ to any significant extent, due to the strong tetrahedral site preference of $\mathrm{Zn}$. Supporting evidence for this assumption will be given below, and even if this assumption would not hold strictly, the following deductions would not become invalid. Within the stability field of cordierite + spinel in the $\mathrm{MgO}-\mathrm{Al}_{2} \mathrm{O}_{3}-\mathrm{SiO}_{2}$ system a two-phase field cordierite $+\mathrm{Mg}$-rich spinel is to be expected in the $\mathrm{ZnO}$-bearing system. This will be separated from a field quartz + Zn-rich spinel by a three-phase field cordierite + spinel + quartz, which represents the subject of the present study. The composition of this spinel is fixed, at given $\mathrm{P}$ and $\mathrm{T}$, by the phase

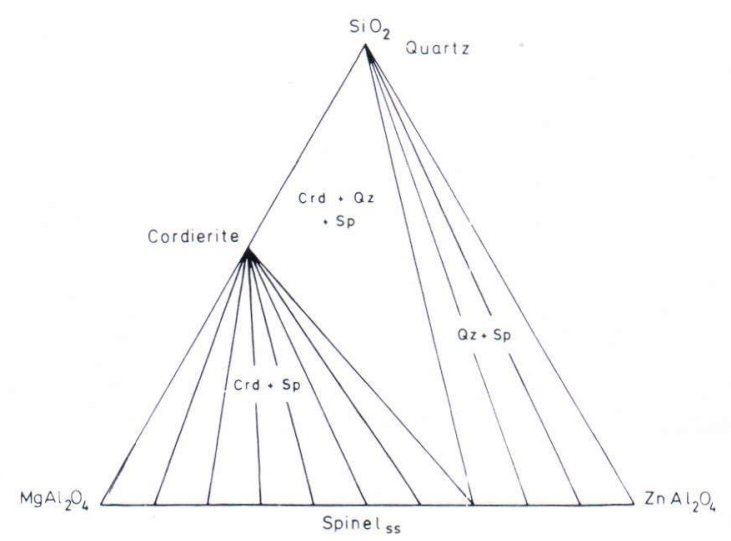

Fig. 1. Expected phase relationships in the anhydrous system $\mathrm{MgAl}_{2} \mathrm{O}_{4}-\mathrm{ZnAl}_{2} \mathrm{O}_{4}-\mathrm{SiO}_{2}$ at elevated temperatures and low pressures. Note the invariancy of the spinel $(\mathrm{Sp})$ composition coexisting with quartz $(\mathrm{Qz})$ and cordierite $(\mathrm{Crd})$ at fixed $\mathrm{P}-\mathrm{T}$ conditions.

rule. When a further component entering any of the participating phases is added to the system (such as $\mathrm{FeO}$ ), the spinel composition in this assemblage will be a function of pressure, temperature, and bulk rock chemistry.

\section{Calculation of the cordierite - spinel - quartz equilibrium in the system $\mathrm{MgAl}_{2} \mathrm{O}_{4}-\mathrm{SiO}_{2}$}

In this system, the phases spinel (sp), cordierite (crd) and quartz (qz) are related by a univariant rection

$$
\begin{aligned}
& \mathrm{Mg}_{2} \mathrm{Al}_{4} \mathrm{Si}_{5} \mathrm{O}_{18} \\
& 5 \mathrm{SiO}_{5}(\mathrm{Mg} \text {-crd })
\end{aligned}=2 \mathrm{MgAl}_{2} \mathrm{O}_{4}(\mathrm{sp})+
$$

For this equilibrium we may obtain the thermodynamic parameters by starting from those given for the participating phases by Helgeson et al. (1978). It is assumed here that the $\Delta \mathrm{V}$ of the reaction is not a function of pressure and temperature. The thermodynamic properties of lowquartz will be used throughout the paper. Possible structural discontinuities in cordierite as postulated by Mirwald (1982) are ignored.

For reaction (1) we thus derive the following thermodynamic parameters: 


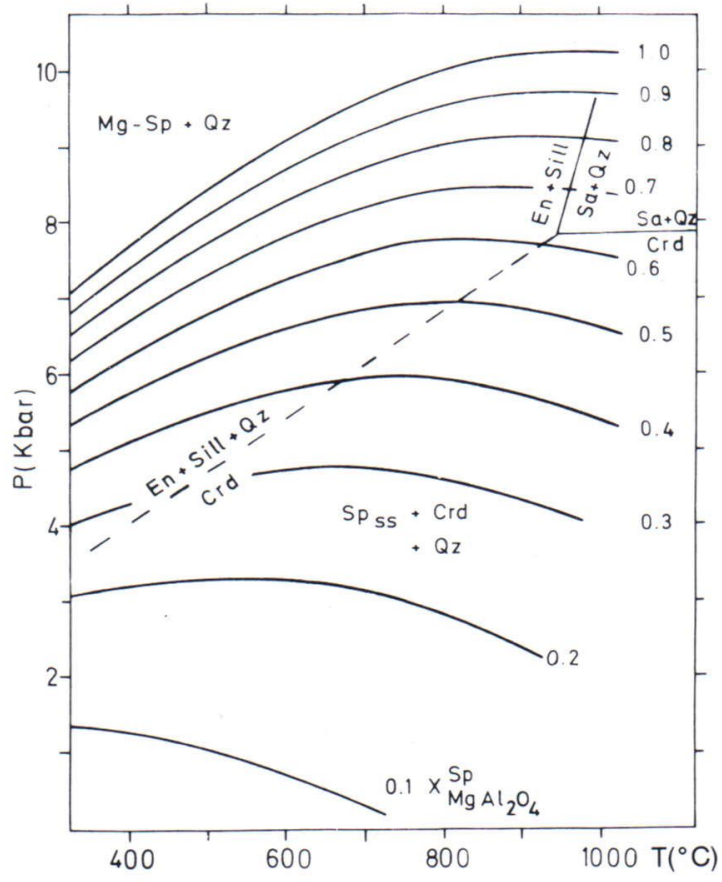

Fig. 2. Calculated $\mathrm{X}^{\mathrm{sp}}{ }_{\mathrm{Mg}}$ isopleths for $\mathrm{MgAl}_{2} \mathrm{O}_{4}-\mathrm{ZnAl}_{2} \mathrm{O}_{4}$ spinels in coexistence with $\mathrm{Mg}$-cordierite and quartz. The dashed lines represent the stability limits of anhydrous $\mathrm{Mg}$ cordierite according to Newton et al. (1974). Abbreviations: $\mathrm{Crd}=$ cordierite, $\mathrm{Sa}=$ sapphirine, $\mathrm{Qz}=$ quartz, $\mathrm{En}=$ enstatite, Sill $=$ sillimanite.

$$
\begin{aligned}
& \Delta \mathrm{G}^{\circ}{ }_{\mathrm{R}(298,1)}=4037 \mathrm{cal} \\
& \Delta \mathrm{S}^{\circ}{ }_{\mathrm{R}(298,1)}=-9.39 \mathrm{cal} / \mathrm{K} \\
& \Delta \mathrm{V}^{\circ}{ }_{\mathrm{R}(298,1)}=-0.9646 \mathrm{cal} / \mathrm{bar} \\
& \Delta \mathrm{C}_{\mathrm{P}}=-14.18+0.02803 \mathrm{~T}+5.682 \times \\
& 10^{5} \mathrm{~T}^{-2} \mathrm{cal} / \mathrm{K}
\end{aligned}
$$

where $\Delta \mathrm{G}^{\circ}{ }_{\mathrm{R}(298,1)}, \Delta \mathrm{S}_{\mathrm{R}(298,1)}^{\circ}$, and $\Delta \mathrm{V}_{\mathrm{R}(298,1)}^{\circ}$ represent the Gibbs free energy change, entropy change, and volume change of the reaction at $298.15 \mathrm{~K}$ and 1 bar. $\Delta \mathrm{C}_{\mathrm{P}}$ is the change in isobaric heat capacity and $\mathrm{T}$ is temperature (in $\mathrm{K}$ ).

Using the format of calculation proposed by Carmichael (1977) we may then calculate $\Delta \mathrm{G}^{\circ}{ }_{\mathrm{R}}$ as a function of temperature. To derive the equilibrium pressure for (1) at a given temperature, the relationship

$$
\begin{aligned}
& \Delta \mathrm{G}_{\mathrm{R}(\mathrm{T}, \mathrm{P})}^{\circ}=\Delta \mathrm{G}_{\mathrm{R}(\mathrm{T}, 1)}^{\circ}+\Delta \mathrm{V}^{\circ} 1_{\mathrm{R}}(\mathrm{P}-1) \\
& =0
\end{aligned}
$$

(Carmichael 1977) is used, where P stands for pressure (in bars). In the PT-field, equilibrium (1) corresponds to a (metastable) univariant curve, which intersects the 1 bar line at $-210^{\circ} \mathrm{C}$ and $2000^{\circ} \mathrm{C}$ and which attains a maximum pressure of $10.3 \mathrm{kbars}$ at $975^{\circ} \mathrm{C}$ ( $c f$. curve labelled 1.0 in Figure 2). The high-temperature intersection with the 1 bar line is supported by the experimental study of the system $\mathrm{Mg}$-cordierite Co-cordierite (Wandschneider and Seifert 1984) where a metastable equilibrium among $\mathrm{Mg}$ cordierite, $\mathrm{Mg}$-spinel and cristobalite can be inferred at about $1600^{\circ} \mathrm{C}$.

As an alternative to the thermodynamic data provided by Helgeson et al. (1978), data sets of Robie et al. (1978), Bucher (personal communication 1985) and Harris and Holland (1985) might also be used. The basic result of such calculations are similar to those described above and to those derived in the following on the basis of Helgeson et al.'s (1978) data, but with some systematic deviations: Robie et al. 's (1978) data yield equilibrium pressures ca. 700 bars, and Bucher's (1985) data pressures 1.5 kbars higher than the Helgeson et al. (1978) data, whereas the recent data set of Harris and Holland (1985) for $1000 \mathrm{~K}$ deviates by only +300 bars. Further complications might arise from the temperaturedependent cation distribution in spinel, which has not been considered here. - These discrepancies point to the necessity of a further refinement of the thermodynamic data.

The system $\mathrm{MgAl}_{2} \mathrm{O}_{4}-\mathrm{ZnAl}_{2} \mathrm{O}_{4}-\mathrm{SiO}_{2}$

The effect of a $\mathrm{Zn}$ component in the spinel on equilibrium (1) may be taken into account by

$$
-\mathrm{RT} \ln \mathrm{K}_{1}=\Delta \mathrm{G}_{\mathrm{R}(\mathrm{T}, 1)}^{\circ}+\Delta \mathrm{V}_{\mathrm{R}}(\mathrm{P}-1)
$$

where

$$
\mathrm{K}_{1}=\left(\mathrm{a}^{\mathrm{sp}}{ }_{\mathrm{MgAl}_{2} \mathrm{O}_{4}}\right)^{2}\left(\mathrm{a}^{\mathrm{qz}}{ }_{\mathrm{SiO}_{2}}\right)^{5 /} / \mathrm{a}^{\mathrm{crd}}{ }_{\mathrm{Mg}_{2} \mathrm{Al}_{4} \mathrm{Si}_{5} \mathrm{O}_{18}}
$$

The a's stand for the activities of the components in the phases indicated, and $\mathrm{R}$ is the gas constant. In the system $\mathrm{MgAl}_{2} \mathrm{O}_{4}-\mathrm{ZnAl}_{2} \mathrm{O}_{4}-\mathrm{SiO}_{2}$, cor- 


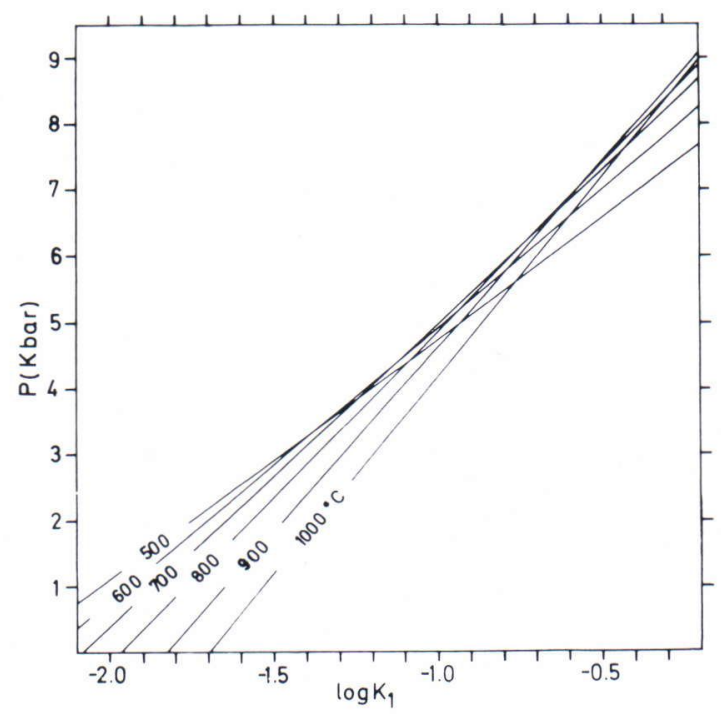

Fig. 3. $\log \mathrm{K}_{1}$ for the cordierite - spinel - quartz equilibrium (1) as a function of pressure for different temperatures.

dierite and quartz are assumed to be pure phases and, hence, a equal to 1 . Thus (4) reduces to

$$
\begin{aligned}
& \mathrm{K}_{1}{ }^{\prime}=\left(\mathrm{X}^{\mathrm{sp}} \mathrm{MgAl}_{2} \mathrm{O}_{4}\right)^{2} \text { with } \mathrm{X}^{\mathrm{sp}} \mathrm{MgAl}_{2} \mathrm{O}_{4}= \\
& \mathrm{Mg} /(\mathrm{Mg}+\mathrm{Zn})
\end{aligned}
$$

The solution of (3) and (4) is given in Fig. 2 in terms of $\mathrm{X}^{\mathrm{sp}} \mathrm{MgAl}_{2} \mathrm{O}_{4}$ isopleths in the PT field. The isopleths form rather flat-lying curves, i.e. the $\mathrm{X}^{\mathrm{sp}}{ }_{\mathrm{Mg}}$ is mostly a function of pressure. Part of the calculated equilibria, in particular those with high $\mathrm{X}_{\mathrm{Mg}}^{\mathrm{sp}}$, will be metastable because cordierite breaks down to assemblages other than spinel + quartz within the field of the divariant reaction (Newton et al. 1974, and Figure 2).

For easier evaluation $\log \mathrm{K}_{1}$ (identical to $\log$ $\mathrm{K}_{1}{ }^{\prime}$ in the $\mathrm{MgAl}_{2} \mathrm{O}_{4}-\mathrm{ZnAl}_{2} \mathrm{O}_{4}-\mathrm{SiO}_{2}$ system) is plotted as a function of pressure and temperature in Fig. 3.

\section{Effect of the FeO component}

For natural assemblages, the $\mathrm{FeO}$ component has to be considered since it can enter both the spinel and the cordierite phase in significant amounts as hercynite $\left(\mathrm{FeAl}_{2} \mathrm{O}_{4}\right)$ and Fe-cor- dierite $\left(\mathrm{Fe}_{2} \mathrm{Al}_{4} \mathrm{Si}_{5} \mathrm{O}_{18}\right)$ end member, respectively. We will first discuss cordierite -- spinel - quartz equilibria in the $\mathrm{Zn}$-free system $\mathrm{MgAl}_{2} \mathrm{O}_{4}$ $\mathrm{FeAl}_{2} \mathrm{O}_{4}-\mathrm{SiO}_{2}$ which contains the complete solid solutions series between Mg-cordierite and $\mathrm{Fe}$-cordierite as well as that between spinel sensu stricto and hercynite.

The reaction

$$
\begin{aligned}
& \mathrm{Fe}_{2} \mathrm{Al}_{4} \mathrm{Si}_{5} \mathrm{O}_{18}(\mathrm{Fe}-\mathrm{crd})=2 \mathrm{FeAl}_{2} \mathrm{O}_{4} \text { (hercynite) } \\
& +5 \mathrm{SiO}_{2}(\mathrm{qz})
\end{aligned}
$$

which is the Fe-analog of equilibrium (1) may be described by its equilibrium constant

$$
\mathrm{K}_{2}=\left(\mathrm{a}^{\mathrm{sp}} \mathrm{FeAl}_{2} \mathrm{O}_{4}\right)^{2}\left(\mathrm{a}^{\mathrm{qz}} \mathrm{SiO}_{2}\right)^{5 /(}\left(\mathrm{a}^{\mathrm{crd}} \mathrm{Fe}_{2} \mathrm{Al}_{4} \mathrm{Si}_{5} \mathrm{O}_{18}\right)
$$

Considering quartz as a pure phase and assuming again ideality for the spinels and setting $\mathrm{a}^{\mathrm{crd}} \mathrm{Fe}_{2} \mathrm{Al}_{4} \mathrm{Si}_{5} \mathrm{O}_{18}=\left(\mathrm{X}_{\mathrm{Fe}}^{\mathrm{crd}}\right)^{2}$ (Thompson 1976) this reduces to

$$
\mathrm{K}_{2}=\left(\mathrm{X}_{\mathrm{Fe}}^{\mathrm{sp}}\right)^{2} /\left(\mathrm{X}_{\mathrm{Fe}}^{\mathrm{crd}}\right)^{2}
$$

Equilibrium (6) has been determined by hydrothermal methods by Richardson (1968) and Holdaway and Lee (1977). In order to compare these data to those of the anhydrous $\mathrm{Mg}$-cordierite breakdown the effect of water on the stability of cordierite has to be removed by using the format of Newton and Wood (1979). Volume data given by Weisbrod (1973) and Robie et al. (1966) yield a $\Delta V_{R(298,1)}^{\circ}$ of $-0.9900 \mathrm{cal} / \mathrm{bar}$. Taking into account that a metastable equilibrium among $\mathrm{Fe}$ cordierite, hercynite, and tridymite can be inferred from the 1 atm liquidus phase diagram (Schairer and Yagi 1952) to lie at about $1200^{\circ} \mathrm{C}$, the dry Fe-cordierite breakdown curve to hercynite and quartz can than be approximated by the relationship

$$
\mathrm{P} \text { (bars) }=5170-4.1 \mathrm{~T}\left({ }^{\circ} \mathrm{C}\right)
$$

The main uncertainty comes from the linear extrapolation of the equilibrium towards lower temperatures, which is equivalent to neglecting the $\Delta \mathrm{C}_{\mathrm{P}}$ term.

$\mathrm{K}_{2}$ can now be evaluated as a function of pressure and temperature from 


$$
\mathrm{K}_{2(\mathrm{P}, \mathrm{T})}=-\Delta \mathrm{V}_{\mathrm{R}(298,1)}^{\circ}\left(\mathrm{P}-\mathrm{P}_{\mathrm{eq}}\right) / \mathrm{RT}
$$

where $\mathrm{P}_{\mathrm{eq}}$ stands for the equilibrium pressure of the end-member reaction at the temperature considered.

For these data and from those of the Mg endmember reaction (1) P-X diagrams for the system Mg-cordierite - Fe-cordierite may be calculated with the format given by Thompson (1976, p. 434). We obtain

$$
\begin{aligned}
& \ln \mathrm{X}^{\mathrm{sp}}{ }_{\mathrm{Fe}} / \mathrm{X}^{\mathrm{crd}} \\
& =\Delta \mathrm{V}_{\mathrm{Fe}}^{\circ}\left(\mathrm{P}_{\mathrm{Fe}}-\mathrm{P}\right) / 2 \mathrm{RT} \\
& \ln \mathrm{X}^{\mathrm{sp}}{ }_{\mathrm{Mg}} / \mathrm{X}^{\mathrm{crd}}{ }_{\mathrm{Mg}} \\
& =\Delta \mathrm{V}^{\circ}{ }_{\mathrm{Mg}}\left(\mathrm{P}_{\mathrm{Mg}}-\mathrm{P}\right) / 2 \mathrm{RT}
\end{aligned}
$$

where $\mathrm{P}_{\mathrm{Mg}}$ and $\mathrm{P}_{\mathrm{Fe}}$ refer to the equilibrium pressure of the two end-member reactions (1) and (6) and $\Delta \mathrm{V}^{\circ}{ }_{\mathrm{Mg}}$ and $\Delta \mathrm{V}^{\circ}{ }_{\mathrm{Fe}}$ to the corresponding volume changes.

By simultaneous solution of the two equations (11) and (12) the divariant $\mathrm{P}-\mathrm{X}$ loops for the breakdown of cordierite into spinel + quartz are derived. Figure 4 illustrates the strong partitioning of $\mathrm{Fe}$ into spinel and of $\mathrm{Mg}$ into the coexisting cordierite. Again, part of the depicted equilibria will be metastable because both the $\mathrm{Mg}$-end member and the Fe-end member of the cordierite solid-solution series break down to assemblages other than spinel + quartz in the temperature range considered (Richardson 1968, and Fig. 2). As to be expected from the small temperature dependence of the end-member reactions the effect of temperature on the compositions of coexisting cordierite and spinels is only slight, particularly in the central portion of the diagram, but the pressure effect is dramatic.

As a next step, we now add the $\mathrm{ZnAl}_{2} \mathrm{O}_{4}$ component to the $\mathrm{Mg}$-Fe system. Phase relations in the system $\mathrm{MgAl}_{2} \mathrm{O}_{4}-\mathrm{ZnAl}_{2} \mathrm{O}_{4}-\mathrm{FeAl}_{2} \mathrm{O}_{4}-\mathrm{SiO}_{2}$, which contains both the binary cordierite and the ternary spinel solid-solution series, may be projected for our purposes from the quartz apex. The singular spinel compositions that than coexist with cordierite and quartz at given $\mathrm{P}$ and $\mathrm{T}$ in the limiting $\mathrm{MgAl}_{2} \mathrm{O}_{4}-\mathrm{ZnAl}_{2} \mathrm{O}_{4}-\mathrm{SiO}_{2}$ (Fig. 2) and $\mathrm{MgAl}_{2} \mathrm{O}_{4}-\mathrm{FeAl}_{2} \mathrm{O}_{4}-\mathrm{SiO}_{2}$ (Figure

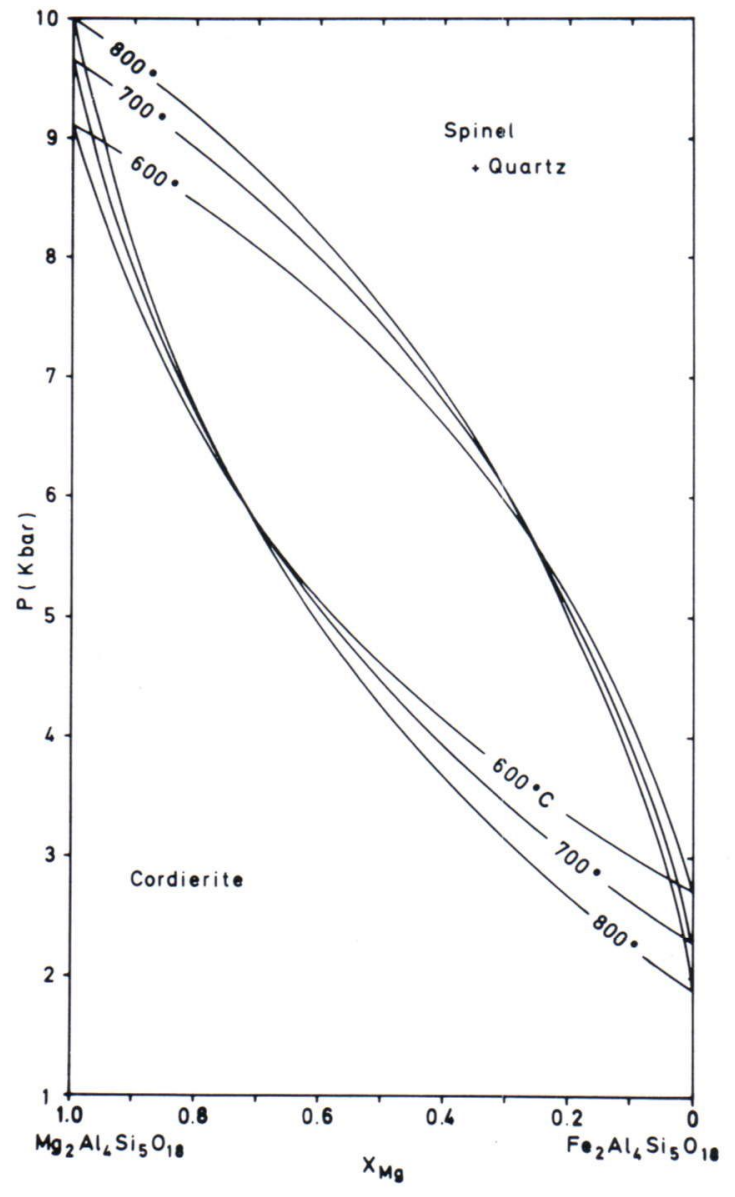

Fig. 4. Calculated compositions of anhydrous $\mathrm{Mg}$-Fe cordierites in coexistence with quartz and $(\mathrm{Fe}, \mathrm{Mg}) \mathrm{Al}_{2} \mathrm{O}_{4}$ spinels at three different temperatures.

4) systems will then, in the combined system, become a line of compositions.

From the two equilibrium constants

$$
\begin{aligned}
& \mathrm{K}_{1}=\left(\mathrm{X}^{\mathrm{sp}}{ }_{\mathrm{Mg}}\right)^{2} /\left(\mathrm{X}^{\mathrm{crd}}{ }_{\mathrm{Mg}}\right)^{2} \\
& =\left(\mathrm{X}^{\mathrm{sp}}{ }_{\mathrm{Mg}}\right)^{2} /\left(1-\mathrm{X}^{\mathrm{crd}}{ }_{\mathrm{Fe}}\right)^{2} \\
& \mathrm{~K}_{2}=\left(\mathrm{X}^{\mathrm{sp}}{ }_{\mathrm{Fe}}\right)^{2} /\left(\mathrm{X}^{\mathrm{rrd}}{ }_{\mathrm{Fe}}\right)^{2}
\end{aligned}
$$

the composition of ( $\mathrm{Mg}, \mathrm{Fe}, \mathrm{Zn})$ aluminate spinels coexisting with quartz and binary $(\mathrm{Fe}-\mathrm{Mg})$ cordierite solid solution can be calculated for any pressure and temperature. Such ternary spinels which are assumed to behave ideally are also described by the mole fractions $\mathrm{X}^{\mathrm{sp}}{ }_{\mathrm{Mg}}=\mathrm{Mg} /$ 

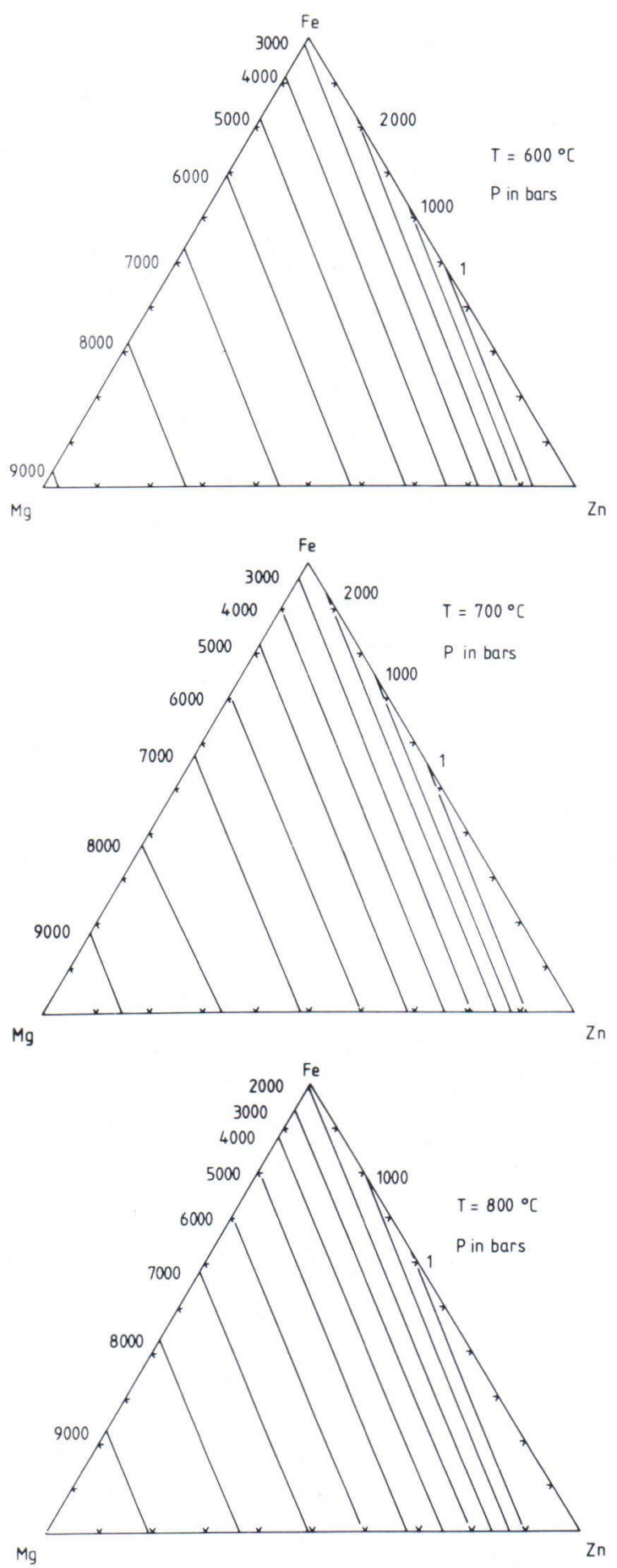

Fig. 5. Calculated compositions of ( $\mathrm{Mg}, \mathrm{Fe}, \mathrm{Zn}) \mathrm{Al}_{2} \mathrm{O}_{4}$ spinels in equilibrium with quartz and anhydrous ( $\mathrm{Mg}, \mathrm{Fe}$ )cordierite as a function of pressure, at three different temperatures.
$(\mathrm{Mg}+\mathrm{Zn}+\mathrm{Fe}), \mathrm{X}_{\mathrm{Fe}}^{\mathrm{sp}}=\mathrm{Fe} /(\mathrm{Mg}+\mathrm{Zn}+\mathrm{Fe})$ and $\mathrm{X}_{\mathrm{Zn}}^{\mathrm{sp}}=\mathrm{Zn} /(\mathrm{Mg}+\mathrm{Zn}+\mathrm{Fe})=1-\mathrm{X}^{\mathrm{sp}}{ }_{\mathrm{Mg}}$ $-\mathrm{X}_{\mathrm{Fe}}^{\mathrm{sp}}$. The combination of (13) and (8) yields, after rearrangement,

$$
\mathrm{X}^{\mathrm{sp}}{ }_{\mathrm{Mg}}=\mathrm{SQRT} \mathrm{K}_{1}-\mathrm{X}^{\mathrm{sp}}{ }_{\mathrm{Fe}} \operatorname{SQRT}\left(\mathrm{K}_{1} / \mathrm{K}_{2}\right)
$$

The results of these calculations is shown in Figure 5 for three different temperatures. Again, the effect of temperature on the composition of spinel coexisting with cordierite and quartz is only slight.

In principle, the two independent equilibrium constants $K_{1}$ and $K_{2}$ could be used for a determination of both pressure and temperature from the compositions of cordierite and spinel coexisting with quartz. Because of the uncertainties in the location of the end-member reactions and their similar slopes at high temperatures, this will not be investigated further. We will return to this problem in the section on $\mathrm{Mg}-\mathrm{Fe}$ distribution after considering the hydrous system.

\section{Effect of water}

In the above model anhydrous conditions have been assumed for the end-member reactions. However, in a natural environment, water may enter the cordierite structure and stabilize it relative to its anhydrous breakdown assemblages (Newton 1972; Newton and Wood 1979). Since the water content in cordierite as a function of pressure, temperature, and composition is still poorly understood and even for pure $\mathrm{Mg}$ cordierite exhibits considerable complexity (Mirwald 1982) and it cannot yet be adequately modelled thermodynamically. As a result, we will evaluate the effect of water only qualitatively. For these gross purposes the model of Newton and Wood (1979) might still serve the needs. For instance at $\mathrm{T}=700^{\circ} \mathrm{C}$ and $\mathrm{P}=5000$ bars (corresponding to a water content in cordierite of about 0.6 moles $\mathrm{H}_{2} \mathrm{O}$ p.f.u., Mirwald 1982) we estimate a stabilization of hydrous cordierite on the order of +1500 bars as compared to anhydrous cordierite. The magnitude of this pressure correction to be applied to data read from 
e.g. Figures 3 and 4 will vary sympathetically with water pressure. From these considerations it follows that any chemical variable that effects the water content in cordierite (such as $\mathrm{CO}_{2}$ or alkalies in the channel of cordierite) will also influence the cordierite-spinel-quartz geobarometer to some extent.

\section{$\mathrm{Fe}-\mathrm{Mg}$ distribution between cordierite and spinel}

The equilibrium constants $\mathrm{K}_{1}$ and $\mathrm{K}_{2}$ given for the end-member reactions (1) and (6) implicitly contain the iron-magnesium distribution coefficient $K_{D}$ between cordierite and spinel, since

$$
\begin{aligned}
& \mathrm{K}_{\mathrm{D}}=\mathrm{X}_{\mathrm{Mg}}^{\mathrm{sp}} \mathrm{X}^{\mathrm{crd}}{ }_{\mathrm{Fe}} / \mathrm{X}_{\mathrm{Fe}}^{\mathrm{sp}} \mathrm{X}^{\mathrm{crd}}{ }_{\mathrm{Mg}} \\
& =\operatorname{SQRT}\left(\mathrm{K}_{1} / \mathrm{K}_{2}\right) .
\end{aligned}
$$

An evaluation is shown in Figure 6. The effect of pressure of $\mathrm{K}_{\mathrm{D}}$ is only slight, due to the small difference in $\Delta V_{R}$ for the end-member reactions, and $\ln \mathrm{K}_{\mathrm{D}}$ is predicted to become more negative with increasing temperature up to some $750^{\circ} \mathrm{C}$ where the trend is reversed. This result is at variance with the deductions by Vielzeuf (1983). Water pressures will affect the end-member equilibrium constants $\mathrm{K}_{1}$ and $\mathrm{K}_{2}$, but the effect on the $\mathrm{Fe}-\mathrm{Mg}$ distribution coefficient will cancel if $\mathrm{K}_{1}$ and $\mathrm{K}_{2}$ are affected in the same way ( $c f$. (14)), i.e. the amount of water and its interaction energetics with the crystal structure are not a function of $\mathrm{X}_{\mathrm{Fe}}^{\mathrm{crd}}$. Then the curves labelled 1 bar and 8 kbars in Figure 6 would describe equally well the dry equilibrium and hydrous equilibria with no influence of $\mathrm{X}_{\mathrm{Fe}}^{\mathrm{crd}}$ on the cordierite water content. If, on the other hand, the equilibrium water content at any given temperature and pressure were also a function of the $\mathrm{Mg} / \mathrm{Fe}$ ratio of cordierite, this would lead to a pronounced effect on $\mathrm{K}_{\mathrm{D}}$. For instance, if the water content of Fe-cordierite were only 0.8 times that of $\mathrm{Mg}$ cordierite at the same temperature and pressure (which is still within the precision of the data available, C. Boberski, pers. comm. 1984),

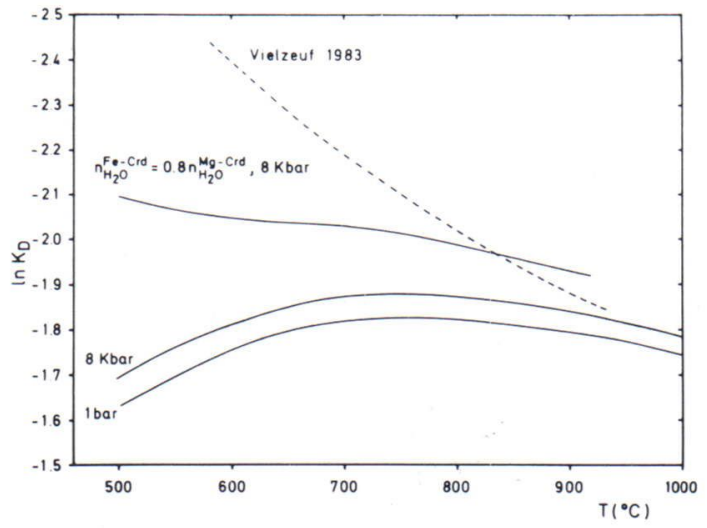

Fig. 6. Predicted Fe-Mg partitioning coefficient, $\ln \mathrm{K}_{\mathrm{D}}$, between cordierite and spinel as a function of temperature, at 1 bar and 8 kbars. The two lower curves are equally valid for the dry system and for the case that the water content of cordierite is not a function of its $\mathrm{Fe} / \mathrm{Mg}$ ratio. With the assumption that the water content of the $\mathrm{Fe}$-cordierite end member is 0.8 times that of the $\mathrm{Mg}$-cordierite end member at any given pressure and temperature the curve in the center results. The relationship proposed by Vielzeuf (1983) is also indicated. For discussion see text.

then the $\mathrm{K}_{\mathrm{D}}$ would behave differently (Figure 6). It is concluded that at least at present the $\mathrm{Fe}-\mathrm{Mg}$ distribution coefficient between cordierite and spinel cannot be used as either a geothermometer, or a barometer.

\section{Natural cordierite - spinel - quartz assemblages}

We have compiled natural cordierite - spinel - quartz assemblages from the literature (see Table 1) for comparison with the predicted behavior of the equilibrium discussed above. In addition, these data serve as a preliminary data set for evaluating the effects of $\mathrm{P}, \mathrm{T}$, and composition of the Fe-Mg distribution between spinel and cordierite. This knowledge will be necessary for assessing the usefulness of the barometer proposed. The following discussion also includes a graphical example of spinel - quartz - cordierite phase relations. 


\section{Phase relations}

In general, natural assemblages will contain more phases than the examples discussed above. We will, therefore, first examine the effects of bulk composition and overall phase relations on the cordierite - spinel - quartz equilibria.

In spinel-bearing rocks the compositions of the spinel reflects its assemblage, which in turn is an indicator of bulk composition. This is schematically illustrated in Figure 7 in the $\mathrm{ZnO}(\mathrm{Z})$ $\mathrm{MgO}(\mathrm{M})-\mathrm{Al}_{2} \mathrm{O}_{3}(\mathrm{~A})-\mathrm{SiO}_{2}(\mathrm{~S})$ and $\mathrm{FeO}(\mathrm{F}) \mathrm{MAS}$ systems at constant $\mathrm{T}$ and $\mathrm{P}$ for one set of phase relations representing upper amphibolite grade. Assemblages involving various combinations of corundum (cor), sillimanite (sill), spinel (sp), cordierite (crd), and quartz (qz), excluding (qz + cor), are reported by Robinson and Jaffe (1969), Schumacher (1983), and Lal et al. (1984), and serve as a basis for this discussion. For aluminous spinel-bearing compositions in both the ZMAS and FMAS systems the same sequence of assemblages is seen as $\mathrm{Mg} / \mathrm{Zn}$ and $\mathrm{Mg} / \mathrm{Fe}$ increases and is as follows: $\mathrm{Qz}+\mathrm{Sill}+\mathrm{Sp}, \mathrm{Qz}$ + Sill + Crd + Sp, Sill + Crd + Sp, Cor + Sill $+\mathrm{Crd}+\mathrm{Sp}$, and Cor $+\mathrm{Crd}+\mathrm{Sp}$. In addition to changes in assemblage, the spinel composition in the ZMAS system (Figure 7A) and both the spinel and cordierite compositions in the FMAS system (Figure 7B) also vary sympathetically with the bulk composition.

Figure 7 further illustrates the special compositional relationship among spinel, cordierite, and quartz, which results from the fact that the cordierite formula can be expressed as quartz + spinel end members (cf. (1)). As a consequence, the coexistence of these three phases fixes the $\mathrm{Zn}$ $\mathrm{Mg}$ ratio of spinel and the $\mathrm{Fe}-\mathrm{Mg}$ ratio of spinel and cordierite at constant $\mathrm{P}$ and $\mathrm{T}$. Because of this the fourth phase of the assemblage (sillimanite) in Figure 7 is not required to specify the compositions of the phases, as is the case with the Crd $+\mathrm{Sp}+$ Sill + Cor assemblage, where no such compositional relationship exists among any three of these phases.

The compositional effects of the strong P de-
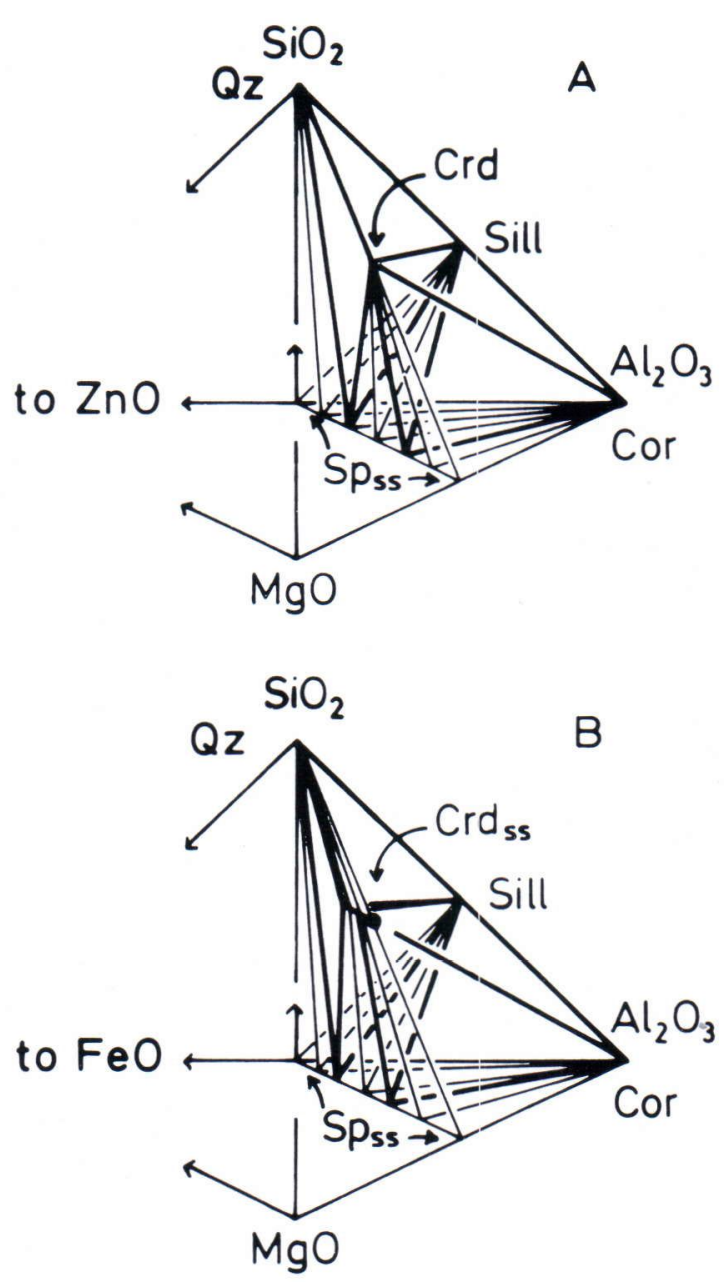

Fig. 7. $\mathrm{ZnO}-\mathrm{MgO}-\mathrm{Al}_{2} \mathrm{O}_{3}-\mathrm{SiO}_{2}$ (A) and $\mathrm{FeO}-\mathrm{MgO}-$ $\mathrm{Al}_{2} \mathrm{O}_{3}-\mathrm{SiO}_{2}$ (B) tetrahedra that show one set of phase relations in these two systems (see text). Crd = cordierite, Cor = corundum, $\mathrm{Qz}=$ quartz, Sill = sillimanite, $\mathrm{Sp}=$ spinel, and subscripted ss $=$ solid solution. Heavy tie lines connect four-phase assemblages and the lighter tie lines connect threephase assemblages. Some $\mathrm{Crd}_{\mathrm{ss}}-$ Sill and $\mathrm{Crd}_{\mathrm{ss}}-\mathrm{Cor}$ tie lines from three-phase assemblages have been left off B for clarity.

pendence of the Sp-Crd-Qz equilibrium, which was discussed previously, can also be visualized in Figure 7. As cordierite stability increases with decreasing $\mathrm{P}$, the four-phase volumes will shift to Zn-richer (Figure 7A) and Fe-richer (Figure 7B) compositions, which results in increasingly $\mathrm{Zn}$ - and Fe-richer spinels coexisting with cordierite and quartz. 
The phase relations in the ZFMAS system are more complex. Here the cordierite $\mathrm{Fe}-\mathrm{Mg}$ ratio and the proportions of $\mathrm{Fe}, \mathrm{Mg}$, and $\mathrm{Zn}$ in spinel can vary. However, at constant $\mathrm{P}$ and $\mathrm{T}$, and at a fixed $\mathrm{X}_{\mathrm{Mg}}$ of cordierite the spinel composition is also fixed, and it would represent a point on a Fe-Mg-Zn spinel compositional ternary. Varying the $X_{\mathrm{Mg}}$ of cordierite would also shift the ternary spinel composition. As a result, at constant $\mathrm{T}$ and $\mathrm{P}$, the spinel compositions that coexist with quartz and cordierite of various $\mathrm{X}_{\mathrm{Mg}}$ values will plot as a line on a Fe-Mg-Zn spinel composition ternary. The contours in Figure 5 represent such sets of spinel compositions calculated at different pressures and temperatures.

\section{Comparison of pressure estimates}

An investigation of natural examples of spinel - cordierite - quartz assemblages was done using the data from sources listed in Table 1. The mole fractions of $\mathrm{MgO}, \mathrm{FeO}$, and $\mathrm{ZnO}\left(\mathrm{X}_{\mathrm{Mg}}\right.$, $\mathrm{X}_{\mathrm{Fe}}, \mathrm{X}_{\mathrm{Zn}}$ ) are listed for spinel and the $\mathrm{X}_{\mathrm{Mg}}$ is given for the coexisting cordierite. It should be noted that $\mathrm{ZnO}$ was analyzed for in some of the cordierite samples (Schumacher 1983; Wolter and Seifert 1984), but was not found. This emphasized that solid solution of $\mathrm{Zn}$ in cordierite is at least negligible, if not totally absent, under normal geologic conditions. In addition, Mncontents of cordierites (Table 1) are very low (less than 0.010 per 18 oxygens). Also listed in Table 1 are the coefficients $K_{1}$ and $K_{2}$, which have been discussed earlier, and $\mathrm{K}_{\mathrm{D}}=\mathrm{K}_{\mathrm{Fe}-\mathrm{Mg}}^{\mathrm{sp}-\mathrm{crd}}=$ $\mathrm{X}^{\mathrm{sp}}{ }_{\mathrm{Mg}} \mathrm{X}^{\mathrm{crd}}{ }_{\mathrm{Fe}} / \mathrm{X}^{\mathrm{sp}}{ }_{\mathrm{Fe}} \mathrm{X}^{\mathrm{crd}}{ }_{\mathrm{Mg}}$. The $\mathrm{T}_{\mathrm{a}}$ and $\mathrm{P}_{\mathrm{a}}(\mathrm{T}, \mathrm{P}$ by the author) estimates given in Table 1 are from the source of the data. The $\mathrm{P}_{\mathrm{m}}\left(\mathrm{P}_{\text {model }}\right)$ values were obtained from Figure 3 using the $\log \mathrm{K}_{1}$ values and $T_{a}$ data. With the exception of sample 6 (Table 1), the $\mathrm{P}_{\mathrm{m}}$ estimate is lower (generally within $1.5 \mathrm{kbar}$ ) than the $\mathrm{P}_{\mathrm{a}}$ estimate. The low $\mathrm{P}_{\mathrm{m}}$ values may result from the stabiliz-

Table 1. Compositional data, distribution coefficients, and P-T data for natural cordierites and spinels coexisting with quartz. $\mathrm{X}_{\mathrm{Mg}}=\mathrm{Mg} /\left(\mathrm{Mg}+\mathrm{Fe}^{+2}+\mathrm{Zn}\right), \mathrm{X}_{\mathrm{Fe}}=\mathrm{Fe}^{+2} /\left(\mathrm{Mg}+\mathrm{Fe}^{+2}+\mathrm{Zn}\right), \mathrm{X}_{\mathrm{Zn}}=1-\mathrm{X}_{\mathrm{Fe}}-\mathrm{X}_{\mathrm{Mg},} \mathrm{K}_{1}=\left(\mathrm{X}_{\mathrm{Mg}}^{\mathrm{sp}}\right)^{2} /\left(\mathrm{X}_{\mathrm{Mg}}^{\mathrm{crd}}\right)^{2}, \mathrm{~K}_{2}=\left(\mathrm{X}_{\mathrm{Fe}}^{\mathrm{sp}}\right)^{2} /$ $\left(\mathrm{X}_{\mathrm{Fe}}^{\mathrm{crd}}\right)^{2}$, and $\mathrm{K}_{\mathrm{D}}=\left(\mathrm{X}_{\mathrm{pg}}^{\mathrm{sg}} \cdot \mathrm{X}_{\mathrm{Fe}}^{\mathrm{crd}}\right) /\left(\mathrm{X}_{\mathrm{Fe}}^{\mathrm{se}} \cdot \mathrm{X}_{\mathrm{Mg}}^{\mathrm{crd}}\right)$. $\mathrm{T}_{\mathrm{a}}$ and $\mathrm{P}_{\mathrm{a}}=$ temperature and pressure estimates based on other geothermometers and barometers for the various terrains as given by the authors. $\mathrm{P}_{\mathrm{m}}=$ pressure estimated from Figure 3 (see text). $\mathrm{T}_{\mathrm{a}}$ for samples $8-12, \mathrm{P}_{\mathrm{a}}$ for samples $16-19$ represent averages of $\mathrm{P}$ and $\mathrm{T}$ ranges.

\begin{tabular}{|c|c|c|c|c|c|c|c|c|c|c|c|}
\hline $\begin{array}{l}\text { Sample } \\
\text { No. }\end{array}$ & $X_{\text {Mg }}^{\text {sp }}$ & $\mathrm{X}_{\mathrm{Fe}}^{\mathrm{sp}}$ & $X_{Z n}^{S p}$ & $\mathrm{X}_{\mathrm{Mg}}^{\mathrm{crd}}$ & $\mathrm{K}_{1}$ & $\mathrm{~K}_{2}$ & $\mathrm{~K}_{\mathrm{D}}$ & $\begin{array}{c}\mathrm{T}_{\mathrm{a}} \\
\left({ }^{\circ} \mathrm{C}\right) \\
\end{array}$ & $\begin{array}{c}\mathrm{P}_{\mathrm{a}} \\
\text { (kbar) }\end{array}$ & $\underset{\text { (kbar) }}{\mathrm{P}_{\mathrm{m}}}$ & Reference \\
\hline 1 & 0.340 & 0.660 & 0.000 & 0.810 & 0.176 & 12.07 & 0.121 & 900 & $7 \pm 1$ & 6.0 & Lal et al. (1984 \\
\hline 2 & 0.355 & 0.590 & 0.055 & 0.840 & 0.179 & 13.60 & 0.115 & 900 & $7 \pm 1$ & 6.0 & Lal et al. (1984) \\
\hline 3 & 0.328 & 0.672 & 0.000 & 0.810 & 0.164 & 12.51 & 0.114 & 900 & $7 \pm 1$ & 5.7 & Lal et al. (1984) \\
\hline 4 & 0.404 & 0.575 & 0.022 & 0.872 & 0.215 & 20.18 & 0.103 & 900 & $7 \pm 1$ & 6.5 & Lal et al. (1984) \\
\hline 5 & 0.313 & 0.665 & 0.021 & 0.792 & 0.156 & 10.22 & 0.131 & 800 & $6 \pm 1$ & 5.6 & Lal et al. (1984) \\
\hline 6 & 0.224 & 0.766 & 0.010 & 0.694 & 0.104 & 6.27 & 0.129 & 730 & 4.3 & 5.0 & Loomis $(1972,1976)$ \\
\hline 7 & 0.204 & 0.288 & 0.508 & 0.834 & 0.060 & 3.01 & 0.141 & 675 & 6.5 & 4.0 & Cornen (1980) \\
\hline $8^{a}$ & 0.505 & 0.495 & 0.000 & 0.891 & 0.321 & 20.62 & 0.125 & 940 & 7 & 7.5 & Ellis et al. (1980) \\
\hline 9 & 0.084 & 0.155 & 0.761 & 0.731 & 0.013 & 0.33 & 0.199 & 610 & $<3.8$ & 1.2 & Dietvorst (1980) \\
\hline 10 & 0.126 & 0.246 & 0.629 & 0.731 & 0.030 & 0.84 & 0.189 & 610 & $<3.8$ & 2.5 & Dietvorst (1980) \\
\hline 11 & 0.081 & 0.286 & 0.633 & 0.607 & 0.018 & 0.53 & 0.184 & 610 & $<3.8$ & 1.8 & Dietvorst (1980) \\
\hline 12 & 0.078 & 0.219 & 0.702 & 0.607 & 0.017 & 0.31 & 0.234 & 610 & $<3.8$ & 1.7 & Dietvorst (1980) \\
\hline 13 & 0.091 & 0.464 & 0.445 & 0.630 & 0.021 & 1.57 & 0.115 & 550 & 2.5 & 2.3 & Wolter and Seifert (1984) \\
\hline 14 & 0.067 & 0.395 & 0.538 & 0.630 & 0.011 & 1.14 & 0.098 & 550 & 2.5 & 1.2 & Wolter and Seifert (1984) \\
\hline 15 & 0.106 & 0.225 & 0.638 & 0.709 & 0.022 & 0.60 & 0.192 & 550 & 2.5 & 2.2 & Wolter and Seifert (1984) \\
\hline 16 & 0.284 & 0.277 & 0.439 & 0.887 & 0.103 & 6.01 & 0.130 & 625 & 6.5 & 5.1 & Schumacher (1983) \\
\hline 17 & 0.392 & 0.442 & 0.166 & 0.887 & 0.195 & 15.30 & 0.113 & 625 & 6.5 & 6.3 & Schumacher (1983) \\
\hline 18 & 0.291 & 0.336 & 0.373 & 0.880 & 0.109 & 7.84 & 0.118 & 625 & 6.5 & 5.2 & Schumacher (1983) \\
\hline 19 & 0.342 & 0.383 & 0.275 & 0.880 & 0.151 & 10.19 & 0.122 & 625 & 6.5 & 5.8 & Schumacher (1983) \\
\hline $20^{\mathrm{b}}$ & 0.123 & 0.853 & 0.024 & 0.522 & 0.056 & 3.19 & 0.132 & 750 & 4.8 & 3.7 & Schumacher 1984, unpubl. \\
\hline
\end{tabular}

a Ellis et al. (1980) give 8-10 kbar but Grew (personal communication, 1984) considers 7 kbars more realistic.

b Sample from Bodenmais, Bavaria. $\mathrm{P}_{\mathrm{a}}$ estimated from composition of garnet coexisting with cordierite (Thompson 1976). 
ing effect of $\mathrm{H}_{2} \mathrm{O}$ in cordierite, which was not considered in the calculations used to derive $\mathrm{K}_{1}$ ( $c f$. section on effect of water).

For further comparison of the natural spinels and the calculated isobaric and isothermal compositions for the ternary spinels the data are plotted in Figure 8. The isobars at $700^{\circ} \mathrm{C}$ were chosen because this temperature is an approximate average of the $\mathrm{T}$ range of the natural samples. In addition it is evident from Figure 3 that the effects of $\mathrm{T}$ between 600 and $800^{\circ} \mathrm{C}$ are fairly small ( $\pm 0.5 \mathrm{kbar}$ ) above $2.5 \mathrm{kbar}$. Pressure estimates $\mathrm{P}_{\mathrm{a}}(\mathrm{kbar})$ for the various terranes are shown next to the analysis points. It should be noted that the pressure estimates for the natural examples obtained from Figure 8 are in good agreement with the estimates listed in Table 1 , which were obtained using the $\mathrm{Mg}$ end-member data only. If any real difference exists between the two sets of pressures, those read from Figure 8 are slightly higher (less than 500 bars on the average) than $P_{m}$. This could indicate a very minor inconsistency between the exact location of the end-member reactions used in the calculations or could reflect slight differences in water content of cordierite as a function of $\mathrm{X}_{\mathrm{Fe}}$ (see above).

The two pairs of spinel analyses connected by tie lines in Figure 8 span the composition range of individual spinels from two samples. These spinels may have equilibrated during the fairly rapid decompression postulated for this locality (Schumacher 1983; Robinson and Jaffe 1969). The variation in $\mathrm{Zn}$ content of these spinels may reflect the various pressures at which the spinel was last in equilibrium with both quartz and cordierite. Consequently, the 6.8 to 5.4 kbar pressure range suggested by these spinels (Figure 8) is reasonable. Two other sets of spinel data from Wolter and Seifert (1984) and Dietvorst (1980) in Figure 8 (labelled W and D) show a range in spinel compositions; however, the trend is nearly parallel to the isobars, and most likely reflects variations in bulk composition. Taken as a whole, the above natural examples agree well

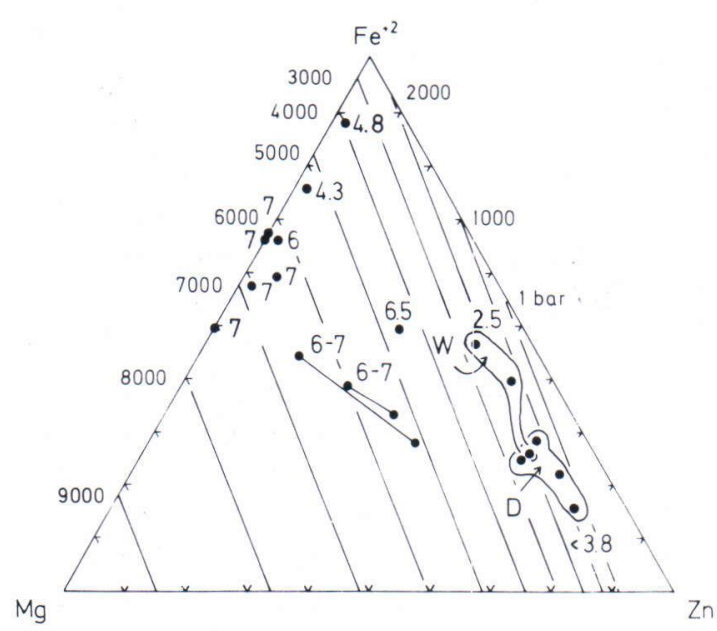

Fig. 8. Ternary plot that compares compositions of natural $\left(\mathrm{Mg}, \mathrm{Fe}^{+2}, \mathrm{Zn}\right.$ ) aluminate spinels (filled circles) from Table 1 to the calculated spinel compositions in equilibrium with cordierite and quartz at $700^{\circ} \mathrm{C}$ and various pressures. Pressure estimates from the data $\left(\mathrm{P}_{\mathrm{a}}, \mathrm{kbar}\right.$, for sources see Table 1) are shown next to the point. Fields labelled W and D represent multiple samples from two localities. Tie lines show the range in composition of spinels from two samples (see text).

with the predicted pressures for the composition of $\mathrm{Mg}-\mathrm{Fe}-\mathrm{Zn}$ spinels coexisting with quartz and cordierite.

The calculations suggest that $\mathrm{K}_{\mathrm{D}}$ is relatively insensitive to pressure and temperature variations and would not be particularly affected by retrograde reequilibration. As a result, in the absence of quartz, cordierite - spinel assemblages could be used to give maximum $\mathrm{P}$ estimates. Spinel analyses highest in $\mathrm{Zn}$ and lowest in $\mathrm{Mg}$ from cordierite- bearing rocks will give the lowest (nearest to actual) pressure estimate (compare Figure 2). As an example, the lowest maximum $\mathrm{P}$ estimated from Berg (1977) for cordierite $\left(\mathrm{X}_{\mathrm{Mg}}\right.$ $=0.642)$ and spinel $\left(\mathrm{X}_{\mathrm{Mg}}=0.178\right)$ is $4.3 \mathrm{kbar}$ (from Figure 3) which is in reasonable agreement with Newton's (1983) 2.45-3.80 kbar estimates for this terrane.

Quartz - spinel assemblages give minimum $\mathrm{P}$ estimates, and spinel analyses lowest in $\mathrm{Zn}$ and richest in $\mathrm{Mg}$ from quartz-bearing assemblages will give the highest (closest to actual) minimum 
$\mathrm{P}$ estimate (compare Figure 2). Spinel from a cordierite-free assemblage from Dietvorst (1980) gives $1.3 \mathrm{kbar}$ (from Figure 8 ), which is consistent with the $3.8 \mathrm{kbar}$ maximum $\mathrm{P}$ estimated by the author, and the 1.2 to $2.5 \mathrm{kbar}$ estimated from the cordierite-bearing assemblage (Table 1).

\section{$\mathrm{Fe}-\mathrm{Mg}$ distribution between spinel and cordierite}

Recently Vielzeuf (1983) has suggested that the $\mathrm{Fe}-\mathrm{Mg}$ distribution between spinel and cordierite is temperature dependent. However, values of $\ln$ $\mathrm{K}_{\mathrm{D}}$ versus temperature for samples used in Table 1 suggest there is very little correlation between these parameters (Figure 9A, compare with Figure 6). The average $\ln \mathrm{K}_{\mathrm{D}}$ from the data used here is $-2.055\left(\mathrm{~K}_{\mathrm{D}}=0.120\right)$. This value is systematically lower than that predicted by the theoretical treatment $(-1.63$ to -1.87$)$ and this difference might be due to the effect of water in cordierite (see above, and Figure 6).

With the limited number of examples presented here it is even more difficult to determine the effects of pressure on $\ln K_{D}$ (Figure 9B). If the data point at $2.5 \mathrm{kbar}$ is ignored, then the $\ln \mathrm{K}_{\mathrm{D}}$ appears to decrease with increasing pressure (in agreement with theory, see Figure 6); however, if the three data points (from the same source) with the largest in $\mathrm{K}_{\mathrm{D}}$ (approximately -1.650 , Figure 9B) are ignored, then the data would suggest that there is no correlation with pressure.

A possible explanation for the variation in $\ln$ $\mathrm{K}_{\mathrm{D}}$ is that this parameter is affected by the $\mathrm{Zn}$ content of the spinel. Figure 9C shows that there seems to be a slight but systematic increase in ln $\mathrm{K}_{\mathrm{D}}$ where the spinel contains more than about $0.3 \mathrm{Zn}$ per 4 oxygens $\left(\mathrm{X}_{\mathrm{Zn}}>0.3\right)$. This would mean that at higher $\mathrm{Zn}$ contents $\mathrm{Mg}$ is increasingly favored over $\mathrm{Fe}$ in spinel, which in turn might suggest a nonideality in the $\mathrm{Zn}, \mathrm{Mg}$, and Fe substitution in $\mathrm{Zn}$-rich spinels. The validity of this relationship could further be studied using Zn-bearing spinel - cordierite pairs from quartzfree rocks, and compilation of these data is in
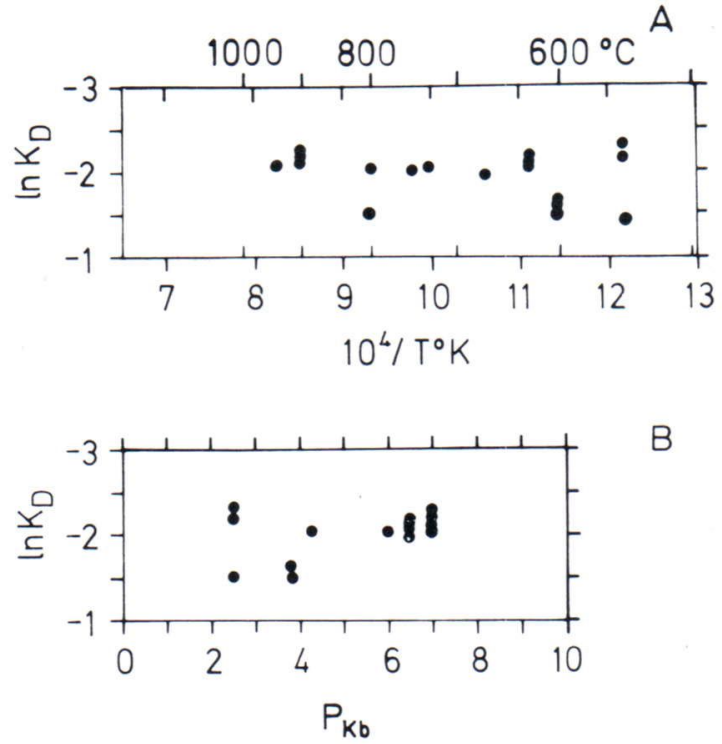

B

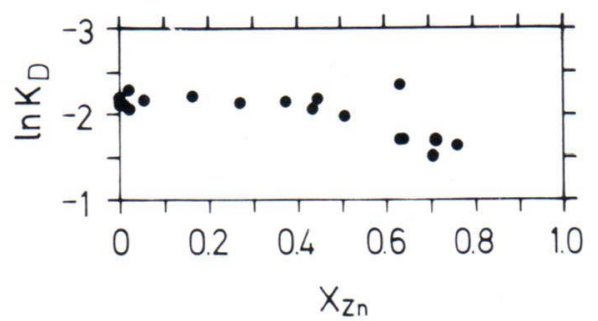

Fig. 9. Plots of $\ln K_{D}$ versus temperature (A), pressure (B), and $\mathrm{X}_{\mathrm{Zn}}$ of spinel $(\mathrm{C})$ for the spinel - cordierite pairs in Table 1. $\ln \mathrm{K}_{\mathrm{D}}=\ln \left(\mathrm{X}^{\mathrm{sp}}{ }_{\mathrm{Mg}} \mathrm{X}^{\mathrm{crd}}{ }_{\mathrm{Fe}}\right) /\left(\mathrm{X}_{\mathrm{Fe}}^{\mathrm{sp}} \mathrm{X}^{\mathrm{crd}}{ }_{\mathrm{Mg}}\right) \cdot \mathrm{X}_{\mathrm{Mg}}=\mathrm{Mg} /$ $\left(\mathrm{Mg}+\mathrm{Fe}^{+2}\right), \mathrm{X}_{\mathrm{Fe}}=\mathrm{Fe}^{+2} /\left(\mathrm{Mg}+\mathrm{Fe}^{+2}\right) \cdot \mathrm{X}_{\mathrm{Zn}}=\mathrm{Zn} /(\mathrm{Mg}+$ $\left.\mathrm{Fe}^{+2}+\mathrm{Zn}\right)$.

progress. If it proves necessary, these additional data could be used to help model the effects of high $\mathrm{Zn}$ in the spinels in the proposed geobarometer.

The strong pressure effect of the cordierite spinel - quartz equilibrium (1) on the $X_{\mathrm{Mg}}$ of cordierite and spinel is shown in Figure 10. Because of the possible $\mathrm{Zn}$ effect on $\mathrm{X}^{\mathrm{sp}}{ }_{\mathrm{Mg}}$, Zn-rich spinels ( $>0.05 \mathrm{Zn}$ per 4 oxygens) are omitted from Figure 10, but the cordierites were all plotted. The data for cordierite and coexisting $\mathrm{Zn}$-poor spinel represent the limbs of a $\mathrm{P}-\mathrm{X}_{\mathrm{Mg}}$ loop, and they are in good agreement with the calculated $\mathrm{P}-\mathrm{X}_{\mathrm{Mg}}$ loop for $700^{\circ} \mathrm{C}$ (from Figure 


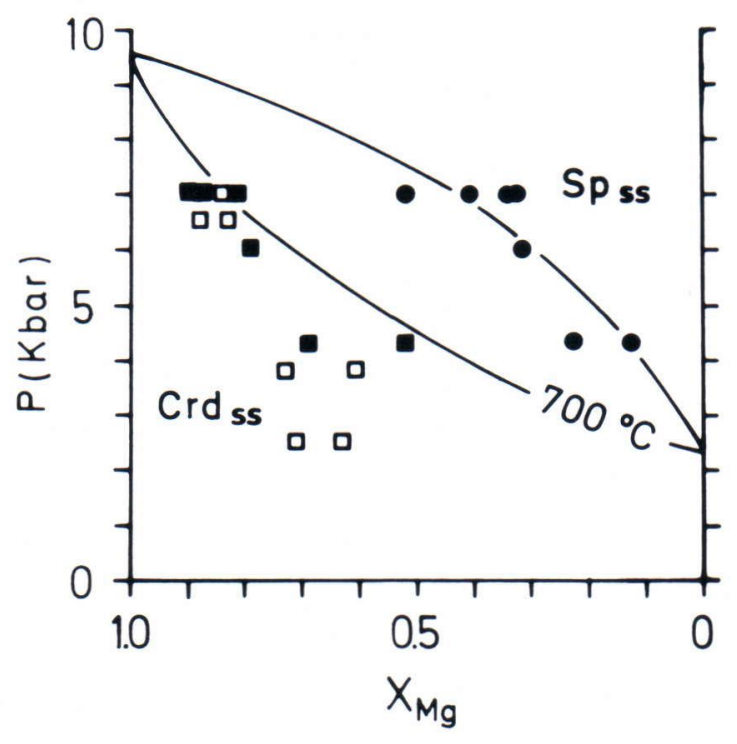

Fig. 10. Plot of $\mathrm{P}$ (kbar) versus $\mathrm{X}_{\mathrm{Mg}}\left(\mathrm{Mg} /\left(\mathrm{Mg}+\mathrm{Fe}^{+2}\right)\right.$ ) for cordierite (squares) and spinels (circles). Filled symbols represent spinel - cordierite pairs where the spinel contains less than $0.05 \mathrm{Zn}$ per 4 oxygens. Spinels with higher $\mathrm{Zn}$ contents are not shown (see text). Open squares are cordierites coexisting with $\mathrm{Zn}$-rich spinels. Some symbols represent more than one analysis.

4). Because of the stabilizing effect of $\mathrm{Zn}$ in spinel, cordierites coexisting with Zn-rich spinel should have a higher $\mathrm{X}_{\mathrm{Mg}}$ than cordierites coexisting with $\mathrm{Zn}$-free spinel at a given pressure. This can be seen in the natural examples by comparing the cordierites from low- $\mathrm{Zn}$ assemblages (filled squares, Figure 10) to cordierites from high-Zn assemblages (open squares).

\section{Other elements in spinel}

The failure to account for ferric iron in microprobe analyses could affect the $\mathrm{Fe}^{+2} / \mathrm{Mg}$ ratio calculated for an individual spinel. However, spinel stoichiometry can be used to estimate the ferric content, and this is commonly done in the literature. There are additional reasons to believe that the ferric content in most spinels in the rocks under discussion is not large. Work by Turnock and Eugster (1962) on the magnetite - her- cynite join indicates that hercynite has less than about 5 per cent solubility towards magnetite below $500^{\circ} \mathrm{C}$. Higher temperature spinels with greater $\mathrm{Fe}^{+3}$ contents should exsolve magnetite as they cool. Such exsolution in Fe-Mg-Zn-Al spinels is commented on by Ramdohr (1969). In most of the spinel - quartz - cordierite assemblages used here, magnetite, which indicates $\mathrm{Fe}^{+3}$ saturation, was not reported, nor was any exsolution in the spinel discussed. This suggests that these spinels contain less, perhaps much less, than $0.10 \mathrm{Fe}^{+3}$ cations per oxygens.

Incorporation of large amounts of $\mathrm{Mn}$ in spinel (galaxite component, $\mathrm{MnAl}_{2} \mathrm{O}_{4}$ ) could affect the proposed geobarometer. However, in the samples from Table $1 \mathrm{Mn}$ was less than 0.013 per 4 oxygens and generally less than 0.010 per 4 oxygens. In addition, galaxite-rich spinels have only been recognized in relatively Mn-rich rocks, and Essene and Peacor (1983) further suggest that to form galaxite $\mathrm{SiO}_{2}$ activity must be so low as to preclude spessartine formation. For these reasons the $\mathrm{MnO}$ contents of the spinels are not expected to be a problem in the calibration of the barometer.

Work on spinel - olivine assemblages (e.g. Irvine 1965; Engi 1983) have demonstrated that the $\mathrm{Fe}-\mathrm{Mg}$ distribution between these two phases is dependent on the Cr-content of the spinel. As a result $\mathrm{Cr}$ potentially could affect the calibration of the quartz-spinel-cordierite geobarometer. Fortunately, the majority of metamorphic spinels taken from the literature contain little or no $\mathrm{Cr}$. In addition, work by Evans and Frost (1975) and Evans (1977) on metamorphosed ultramafic rocks indicates that original chromites become increasingly more aluminous as metamorphic grade increases. At conditions of the upper amphibolite facies the spinels are either $\mathrm{Cr}$-free or contain only minor $\mathrm{Cr}$, which indicates that $\mathrm{Cr}$ is preferentially incorporated into $\mathrm{Fe}-\mathrm{Mg}-\mathrm{Al}$ silicates rather than into oxides. Consequently, correcting for $\mathrm{Cr}$ in most metamorphic spinels is also not anticipated to be a problem in the application of the barometer. 


\section{Outlook}

It has been demonstrated that, in the assemblage cordierite - spinel - quartz, the composition of the spinel changes drastically with pressure and is slightly temperature dependent. This should make the proposed barometer extremely sensitive to pressure variations. Comparison to natural assemblages supports the model. The application of the new geobarometer to cordierite - anthophyllite rocks that are linked to sulfide deposits might, for instance, help to further elucidate their genesis and tectonic setting: It is generally agreed that the protoliths of most of these rocks originated through rock - seawater interaction at low temperatures and that the present-day assemblage is the product of a later metamorphic event. This event might either be associated with a regional orogeny (with a medium-pressure geothermal gradient) or a seafloor metamorphism characterized by rather high temperatures and very low pressures. If, therefore, rather low pressures could be assessed for

\section{References}

Berg, J. M., 1977. Regional geobarometry in the contact aureoles of the anorthositic Nain Complex, Labrador. J. Petrol. 18, 399-430.

Bunting, E. N., 1932. Phase equilibria in the system $\mathrm{SiO}_{2}-$ $\mathrm{ZnO}-\mathrm{Al}_{2} \mathrm{O}_{3}$. J. Res. Nat. Bureau of Standards 8, 279-287.

Carmichael, D. M., 1977. Chemical equilibria involving pure crystalline compounds. In: Short Course in Application of Thermodynamics to Petrology and Ore Deposits $(\mathrm{H}$. J. Greenwood, ed.), Mineral. Ass. Canada, 47-65.

Cornen, G., 1980. Petrologie des gneiss à gedrite d'Ensalers (Massif Central français). Bull. Minéral. 103, 478-490.

Dietvorst, E. J. L., 1980. Biotite breakdown and the formation of gahnite in metapelitic rocks from Kemiö, Southwest Finland. Contrib. Mineral. Petrol. 75, $327-337$.

Ellis, D. J.; Sheraton, J. W.; England, R. N., \& Dallwitz, W. B., 1980. Osumilite - sapphirine - quartz granulites from Enderby Land Antarctica - Mineral assemblages and reactions. Contrib. Mineral. Petrol. 72, $123-143$. such cordierite-anthophyllite rocks, this could be taken as evidence for a single process that lead, in its initial stages at low temperatures, to the formation of the protolith and, subsequently, to the formation of the high-grade assemblage at higher temperatures.

For a further refinement of the barometer data on the hydration state of cordierite as a function of $\mathrm{P}, \mathrm{T}$, and $\mathrm{X}$ (including gaseous species), and the activity - composition relationship of both cordierite and spinel will be required. An experimental study of the $\mathrm{Mg}$-cordierite $-(\mathrm{Mg}$, $\mathrm{Zn}$ )-spinel - quartz equilibrium is presently under way. This is coupled with an application of the data to natural assemblages on a regional scale in Scandinavia.

Acknowledgements. We thank Deutsche Forschungsgemeinschaft, Bonn, for financial support. Critical reviews of the manuscript by R. C. Newton, M. Raith, W. Schreyer and F. Spear are appreciated. We also thank W. Schreyer for providing the sample from Bodenmais, Bavaria and $\mathrm{K}$. Bucher for communicating a data set of thermodynamic properties.

Engi, M., 1983. Equilibria involving Al-Cr spinel: Mg-Fe exchange with olivine. Experiments, thermodynamic analysis, and consequences for geothermometry. Am. J. Sci. 283-A, 29-71.

Eskola, P., 1914. On the petrology of the Orijärvi region in southwestern Finland. Bull. Comm. Geol. Finl. 40, $1-277$.

Essene, E. J., \& Peacor, D. R., 1983. Crystal chemistry and petrology of coexisting galaxite and jacobsite and other spinel solutions and solvi. Am. Mineral. 68, 449-455.

Evans, B. W., 1977. Metamorphism of alpine peridotite and serpentinite. Ann. Rev. Earth Plan. Sci. Letters 5, $397-447$.

- and Frost, B. R., 1975. Chrome-spinel in progressive metamorphism - A preliminary analysis. Geochim. Cosmochim. Acta 39, 955-972.

Harris, N. B. W., and Holland, T. J. B., 1985. The significance of cordierite-hypersthene assemblages from the Beitbridge region of the Central Limpopo Belt; evidence for rapid decompression in the Archean? Am. Mineral. in the press.

Helgeson, H. C.; Delany, J. M.; Nesbitt, H. W. \& Bird, D. $K ., 1978$. Summary and critique of the thermodynamic 
properties of rock-forming minerals. Am. J. Sci. 278-A, $1-229$.

Holdaway, M. J. \& Lee, S. M., 1977. Fe-Mg cordierite stability in high-grade pelitic rocks based on experimental, theoretical, and natural observations. Contrib. Mineral. Petrol. 63, 175-198.

Irvine, T. N., 1965. Chromian spinel as a petrogenetic indicator. I. Theory. Can. J. Earth Sci. 2, 648-672.

Lal, R. K.; Ackermand, D.; Raith, M.; Raase, P. \& Seifert, $F$., 1984. Sapphirine-bearing assemblages from Kiranur, Southern India: A study of chemographic relationships in the $\mathrm{Na}_{2} \mathrm{O}-\mathrm{FeO}-\mathrm{MgO}-\mathrm{Al}_{2} \mathrm{O}_{3}-\mathrm{SiO}_{2}-\mathrm{H}_{2} \mathrm{O}$ system. N. Jb. Mineral Abh., 150, 121-152.

Loomis, T. P., 1972. Contact metamorphism of pelitic rocks by the Ronda ultramafic intrusion, southern Spain. Geol. Soc. Am. Bull. 83, 2449-2474.

,- 1976 . Irreversible reactions in high grade metamorphic rocks. J. Petrol. 17, 559-588.

Mirwald, $P . W ., 1982$. High-pressure phase transitions in cordierite. Phys. Earth Planetary Int. 29, 1-5.

Newton, R. C., 1972. An experimental determination of the high-pressure stability limits of magnesian cordierite under wet and dry conditions. J. Geol. 80, 398-420.

-, 1983. Geobarometry of high-grade metamorphic rocks. Am J. Sci. 283-A, 1-28.

-; Charlu, T. V. and Kleppa, O. J., 1974. A calorimetric investigation of the stability of anhydrous magnesium cordierite with application to granulite facies metamorphism. Contrib. Mineral. Petrol. 44, 295--311.

- \& Wood, B. J., 1979. Thermodynamics of water in cordierite and some petrologic consequences of cordierite as a hydrous phase. Contrib. Mineral. Petrol. 68, 391-405.

Ramdohr, P., 1969. The ore minerals and their intergrowths. Pergamon Press. Rankin, G. A. and Merwin, H. E., 1918. The system $\mathrm{MgO}-\mathrm{Al}_{2} \mathrm{O}_{3}-\mathrm{SiO}_{2}$. Am. J. Sci., 4th ser., 45, 301-325.

Richardson, S. W., 1968. Staurolite stability in a part of the system Fe-Al-Si-O-H. J. Petrol. 9, 467-488.

Robie, R. A.; Bethke, P. M.; Toulmin, M. S. \& Edwards, J. L.; 1966. X-ray crystallographic data, densities and molar volumes of minerals. In: Handbook of Physical Constants (S. P. Clark, ed.), Geol. Soc. America Mem.
97, 27-74.

Robie, R. A., Hemingway, B. S., and Fisher, J. R., 1978. Thermodynamic properties of minerals and related substances at $298.15 \mathrm{~K}$ and 1 bar ( $10^{5}$ Pascals) pressure and at higher temperatures. Geol. Survey Bull. 1452, 456 p.

Robinson, P. and Jaffe, H. W., 1969. Aluminous enclaves in gedrite - cordierite gneiss from southwestern New Hamsphire. Am. J. Sci. 267, 389-421.

Schairer, J. F. \& Yagi, K., 1952. The system $\mathrm{FeO}-\mathrm{Al}_{2} \mathrm{O}_{3}-$ $\mathrm{SiO}_{2}$. Am. J. Sci., Bowen Vol., 471-512.

Schumacher, J. C., 1983. Stratigraphic, geochemical, and petrologic studies of the Ammonoosuc Volcanics, Northcentral Massachusetts and Southwestern New Hampshire. Unpubl. Ph. D. thesis, University of Massachusetts, Amherst.

Seifert, F., 1974. Stability of sapphirine: A study of the aluminous part of the system $\mathrm{MgO}-\mathrm{Al}_{2} \mathrm{O}_{3}-\mathrm{SiO}_{2}-\mathrm{H}_{2} \mathrm{O}$. J. Geol. 82, 173-204.

Thompson, A. B., 1976. Mineral reactions in pelitic rocks: I. Prediction of $\mathrm{P}-\mathrm{T}-\mathrm{X}(\mathrm{Fe}-\mathrm{Mg})$ phase relations. II. Calculation of some $\mathrm{P}-\mathrm{T}-\mathrm{X}(\mathrm{Fe}-\mathrm{Mg})$ phase relations. Am. J. Sci. 276, 401-454.

Treloar, P. J.; Koistinen, T. J. \& Bowes, D. R., 1981. Metamorphic development of cordierite - amphibole rocks and mica schists in the vicinity of the Outokumpu ore deposit, Finland. Trans. R. Soc. Edinburgh, Earth Sci. 72, $201-215$.

Turnock, A. C. \& Eugster, H. P., 1962. Fe-Al oxides: phase relationships below $1000^{\circ} \mathrm{C}$. J. Petrol. 3, 533-565.

Vielzeuf, D., 1983. The spinel and quartz associations in high grade xenoliths from Tallante (S.E. Spain) and their potential use in geothermometry and barometry. Contrib. Mineral. Petrol. 82, 301-311.

Wandschneider, P. \& Seifert, F., 1984. The system Mgcordierite - Co-cordierite. J. Am. Ceram. Soc. 67, C163-164.

Weisbrod, A., 1973. Cordierite - garnet equilibria in the system $\mathrm{Fe}-\mathrm{Mn}-\mathrm{Al}-\mathrm{Si}-\mathrm{O}-\mathrm{H}$. Carnegie Inst. Wash. Year Book 72, 515-523.

Wolter, H. U. \& Seifert, F., 1984. Mineralogy and genesis of cordierite - anthophyllite rocks from the sulfide deposit of Falun, Sweden. Lithos 17, 147-152. 